\title{
Obat Kombinasi Hipertensi Ditinjau dari Efektivitas Terapi dan Harga
}

\author{
J es sica, Cyrilla Azaria Dhara Sadhana, Margareta Anindhita Oktaviani, \\ Vik toria Maya Chyntia, Nourmalita Pertamas ari \\ Fak ultas Farmasi, Universitas Sanata Dharma, Yogyakarta, Indonesia
}

Terbit online : 26 November 2016

\section{Abstrak :}

Dewasa ini, biaya pelayanan kesehatan semakin meningkat, sehingga diperlukan pemikiran khusus dalam peningkatan efisiensi atau penggunaan dana secara lebih rasional. Pada tahun 2013 dengan menggunakan unit analisis individu menunjukkan bahwa secara nasional 25,8\% penduduk Indonesia menderita penyakit hipertensi. Pada kombinasi amlodipin-bisoprolol memiliki efek menurunkan tekanan darah sistolik sebesar $13,91 \mathrm{mmHg}$ dan diastolik sebesar $3,48 \mathrm{mmHg}$. Sedangkan amlodipin-furosemide memiliki efek menurunkan tekanan darah sistolk sebesar $12,00 \mathrm{mmHg}$ dan diastolik sebesar $2,92 \mathrm{mmHg}$. Dari segi efektivitas pengobatan, maka kombinasi antara amlodipin-bisoprolol lebih efektif. Dan segi biaya, berdasarkan nilai (Average Cost Effectiveness Ratio) amlodipin-bisoprolol memiliki nilai yang lebih mahal yaitu sebesar Rp 1081.16,- dibandingkan amlodipin-furosemid sebesar Rp 306.37,-. Kemudian untuk nilai ICER (Incremental Cost Effectiveness Ratio) sebesar Rp -34.494,75,-. Berdasarkan data tersebut, maka efektivitas biaya yang paling efektif adalah amlodipin-furosemide.

Keyword : hipertensi, efektivitas terapi, harga obat

\section{Pendahuluan}

Menurut WHO, obat adakh zat yang dapat mempengaruhi aktivitas fisik dan psikis. Dewasa ini, biaya pelayanan kesehatan semakin meningkat, sehingga diperlukan pemikiran khusus dalam peningkatan efisiensi atau penggunaan dana secara lebih rasional.

\section{Apa itu farmakoekonomi?}

Farmakoekonomi dalam kasus ini memiliki kaitan, karena bidang ilmu ini merupakan sebuah penelitian tentang proses identifikasi, mengukur dan membandingkan biaya, resiko dan keuntungan dari suatu program pelayanan dan terapi serta determinasi suatu alternatif terbaik.

\section{Hipertensi}

Hipertensi merupakan 'Silent Killer' di mana gejala dapat bervariasi pada masing-masing individu dan hampir sama dengan gejala penyakit lain. Hipertensi merupakan salah satu faktor penting sebagai pemicu "Penyakit Tidak Menular" (Non Communicable Disease = NCD) seperti penyakit jantung, stroke dan lain-lain yang saat ini menjadi penyebab kematian nomor satu di dunia.

Menurut American Heart Association (AHA), penduduk Amerika yang bensia di atas 20 tahun menderita hipertensi telah mencapai angka hingga 74,5 juta jiwa. Namun hampir sekitar $90-95 \%$ kasus tidak diketahui penyebabnya. 


\section{Hipertensi di Indonesia}

Di Indonesia, hipertensi telah terjadi di seluruh provinsi yang ada. Dapat dilhat dari bagan, mengenai prevalensi hipertensi berdasarkan pengukuran tekanan darah. Pada tahun 2013 dengan menggunakan unit analisis individu menunjukkan bahwa secara nasional $25,8 \%$ penduduk Indonesia menderita penyakit hipertensi.

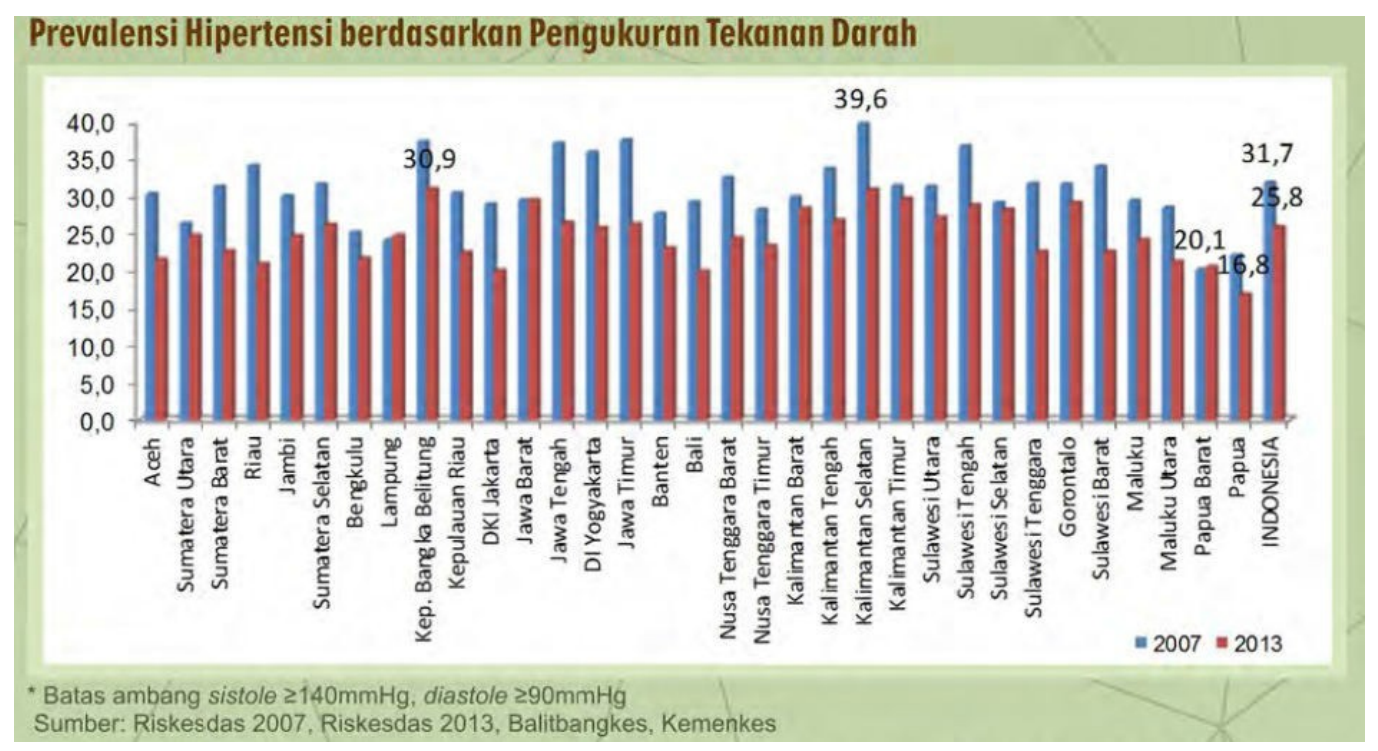

Jika saat ini penduduk Indonesia sebesar 252.124.458 jiwa maka terdapat 65.048.110 jiwa yang menderita hipertensi. Suatu kondisi yang cukup mengejutkan. Terdapat 13 provinsi yang persentasenya melebihi angka nasional, dengan tertinggi di provinsi Bangka Belitung $(30,9 \%)$ atau secara absolut sebanyak $30,9 \%$ × 1.380.762jiwa $=426.655$ jiwa.

\section{Analisis farmakoekonomi obat hipertensi}

Terdapat berbagai macam golongan obat hipertensi yaitu golongan Angiotensin Converiting Enzim Inhibitor (ACEI), Angiotensin Receptor Blocker (ARB), Calcium Channel Blocker (CCB), diuretics, dan $\beta$-Blocker. Amlodipn merupakan contoh golongan obat $\mathrm{CCB}$, kemudian bisoprolol merupakan contoh golongan obat $\beta$-Blocker, serta furosemide merupakan cntoh golongan obat diuretik.

Pada kombinasi amlodipin-bisoprolol memilik efek menurunkan tekanan darah sistolik sebesar $13,91 \mathrm{mmHg}$ dan diastolik sebesar $3,48 \mathrm{mmHg}$. Sedangkan amlodipin-furosemide memiliki efek menurunkan tekanan darah sistolik sebesar $12,00 \mathrm{mmHg}$ dan diastolik sebesar 2,92 $\mathrm{mmHg}$. Dari segi efektivitas pengobatan, maka kombinasi antara amlodipin-bisoprolol lebih efektif.

Dari segi biaya, berdasarkan nilai (Average Cost Effectiveness Ratio) amlodipin-bisoprobl memiliki nilai yang lebih mahal yaitu sebesar Rp 1081.16,- dibandingkan amlodipin-furosemid sebesar Rp 306.37,-. Kemudian untuk nilai ICER (Incremental Cost Effectiveness Ratio) sebesar Rp $-34.494,75,-$. Berdasarkan data tersebut, maka efektivitas biaya yang paling efektif adalah amlodipin-furosemide.

Berdasarkan analisis di atas, kombinasi amlodipin-bisoprolol memiliki efektifitas yang lebih baik dibandingkan dengan amlodipin-furosemid. Namun hal tersebut tidak menjadi alasan pasien untuk memilih pengobatan amlodipin-bisoprolol sebagai terapi lini pertama, karena pengobatan hipertensi juga harus disesuaikan dengan kondisi kesehatan lainnya dari pasien. 
Referensi :

1. Andayani, T. M., 2013, Farmakoekonomi (Prinsip dan Metodologi), Bursa llmu, Yogyakarta.

2. Bakri, S., Lawrence, G.S., 2008. Genetika Hipertensi. Dalam: Lubis, H.R., dkk., eds. 2008. Hipertensi dan Ginjal: Dalam Rangka Purna Bakti Prof. Dr. Harun Rasyid Lubis, Sp.PD-KGH. Medan: USU Press, 19-31

3. Hipertensi, The Silent Killer of Death, 2015, http://www.kompasiana.com/de-be/hipertensithe-silent-killer-of-death_54f8930ba33311 ce098b46cb, diakses 9 November 2016

4. Pusat Data dan Informasi Kementrian Kesehatan Republik Indonesia

5. Wijayanti, 2016, Analisis Efektifitas Biaya Pengobatan Kombinasi Amlodipin Furosemid Dibandingkan dengan Kombinasi Amlodipin Bisoprolol pada Pasien Hipertensi Rawat Jalan di Rsud Undata Palu Periode Agustus-Oktober Tahun 2014, Online Jumal of Natural Science Vol 5(1): 101-110

Artikel ini terbit online di http://farmasetika.com/2016/11/26/obat-kombinasi-hipertensi-ditinjaudari-efektivitas-terapi-dan-hargal 